\title{
KINERJA PROGRAM KESEHATAN DALAM MENJANGKAU MASYARAKAT MISKIN: STUDI TENTANG KAPASITAS MANAJEMEN DALAM PROGRAM JAMINAN KESEHATAN MASYARAKAT (JAMKESMAS) UNTUK KELUARGA MISKIN DI KABUPATEN BANYUMAS
}

\author{
Denok Kurniasih \\ Jurusan Ilmu Administrasi Negara, FISIP, Universitas Jenderal Soedirman Purwokerto \\ Email: denokkurniasih@yahoo.com
}

\begin{abstract}
ABSTRAK. Untuk meningkatkan akses masyarakat miskin terhadap pelayanan kesehatan, pemerintah mengeluarkan kebijakan tentang pemberian jaminan kesehatan yang ditujukan bagi masyarakat miskin (Jamkesmas) di seluruh wilayah di Indonesia. Tugas pemerintah daerah adalah menentukan jumlah kuota yang diusulkan kepada pemerintah pusat untuk mendapatkan Jamkesmas. Namun demikian masalah utama yang masih saja terjadi adalah banyaknya masyarakat miskin yang belum mendapatkan Jamkesmas tersebut, sehingga program tersebut dirasakan belum optimal. Penelitian ini berkenaan dengan masalah rendahnya kinerja program kesehatan, khususnya dalam penyelenggaraan Jamkesmas di Kabupaten Banyumas dalam menjangkau masyarakat miskin. Pengukuran kinerja program Jamkesmas ditujukan pada bagaimana menghasilkan pemenuhan kebutuhan dan kepuasan pasien miskin terhadap tuntutan dan harapan akan pelayanan kesehatan. Hasil penelitian menunjukan bahwa rendahnya kinerja program Jamkesmas ditunjukan oleh rendahnya cakupan pelayanan bagi masyarakat miskin. Masih banyak masyarakat miskin yang belum mendapatkan layanan kesehatan melalui Jamkesmas. Hal tersebut disebabkan oleh rendahnya kapasitas manajemen pemerintah daerah dalam meningkatkan kinerja program. Kapasitas manajemen tersebut meliputi kapasitas anggaran, kapasitas informasi dan kapasitas sumberdaya manusia. Rendahnya kapasitas manajemen menyebabkan banyak masyarakat miskin tidak mendapatkan haknya untuk mendapatkan Jaminan kesehatan yang sebenarnya sudah disediakan pemeritah pusat. Selain disebabkan faktor kapasitas manajemen, rendahnya kinerja program Jamkesmas juga disebabkan adanya aspek politik yang berkembang di Kabupaten Banyumas.
\end{abstract}

Kata kunci : Aspek politik, Kapasitas Manajemen, Kinerja Pemerintah Daerah, Pelayanan Kesehatan Masyarakat Miskin 
Kinerja Program Kesehatan dalam Menjangkau Masyarakat Miskin: Studi Tentang Kapasitas Manajemen dalam Program Jaminan Kesehatan Masyarakat (JAMKESMAS)

untuk Keluarga Miskin di Kabupaten Banyumas (Denok Kurniasih)

\title{
HEALTH PROGRAMME PERFORMANCE IN REACHING THE POOR: A STUDIES OF MANAGEMENT CAPACITY ON PUBLIC HEALTH INSURANCE PROGRAMME FOR THE POOR IN BANYUMAS REGENCY
}

\begin{abstract}
To improve poor people's access to health care, the government issued a policy regarding the provision of health insurance that is intended for the poor (Jamkesmas) in all regions in Indonesia. Local government task is to determine the amount of quota to the central government Jamkesmas acceptance. However the main problem that still occurs is still many poor people who have not received Jamkesmas, so that the program is felt not optimal. The research is concerned with the problem of low performance of health programme, particularly in the case of the implementation of Jamkesmas in Banyumas in reaching the poor. Measuring the performance of health programme aimed at fulfilling the needs and how to produce poor patient satisfaction to the demands and expectations of health care services. The result showed that the low performance of health programme demonstrated by the low coverage of services for the poor. There are still many poor people who do not get health care through Jamkesmas. This was caused by the low management capacity of local governments to improve programmes performance. Capacity management includes budgeting capacity, information capacity and human resource capacity. Low management capacity led to many poor people do not get their right to obtain a health insurance scheme which is already provided pemeritah center. In addition due to management capacity factor, the low performance of Jamkesmas is also due to the political aspects that developed in Banyumas.
\end{abstract}

Keywords: Capacity Management, Local Government Performance, Political Aspects, Poor Health Services

\section{PENDAHULUAN}

Dalam dua dekade terakhir ini, persoalan kinerja organisasi publik terus menjadi topik besar dalam studi administrasi publik (Boyne, 2002; Poister, 2003; Sole, 2009). Hal tersebut disebabkan karena kinerja merupakan elemen penting dalam rangka meningkatkan akuntabilitas publik. Namun demikian hasil review penelitian terakhir mengidentifikasi bahwa persoalan kinerja organisasi publik belum juga beranjak dari masalah inefisiensi, red tape, tidak efektif, tidak fleksibel dan sebagainya. Birokrasi selalu identik dengan organisasi yang lamban, kaku, dan tidak tanggap terhadap terhadap kebutuhan masyarakat (Dwiyanto, 2006; Siddique, 2006; Sole, 2009).

Penelitian ini berkenaan dengan kinerja program dalam bidang kesehatan. Lokus penelitian ini ada pada organisasi pemerintah daerah. Dalam Undang-undang Nomor 32/2004, dijelaskan bahwa bidang pemerintahan yang wajib dilaksanakan oleh daerah kabupaten/kota meliputi pekerjaan umum, kesehatan, pendidikan dan kebudayaan, 
pertanian, perhubungan, industri dan perdagangan, penanaman modal, lingkungan hidup, pertanahan, koperasi dan tenaga kerja. Berangkat dari tataran formal tersebut, maka kinerja program kesehatan pemerintah daerah secara ideal dapat diukur dari sejauh mana pemerintah daerah dapat menjalankan kewajiban-kewajibannya tersebut dalam rangka memberikan pelayanan kesehatan kepada masyarakat.

Urusan kesehatan sebagai salah satu urusan wajib juga terus menjadi prioritas utama dalam program reformasi kesehatan. Bukan saja persoalan penyampaian pelayanannya (service delivery) tetapi yang lebih penting lagi adalah hasil serta dampaknya (outcome). Selama ini organisasi pemerintah daerah terlalu fokus pada input dan proses pelayanan publik tanpa melihat dampak langsung yang dihasilkan dari kinerja mereka. Sebagai contoh pemerintah terus mengupayakan mendapatkan penghargaan dari pemerintah pusat atas kinerja pelayanan publiknya tapi tidak mengukur apakah kinerja mereka berdampak pada pengurangan angka kemiskinan di daerah. Oleh karena itu sudah saatnya dilakukan perubahan mendasar terkait dengan cara pengukuran kinerja program pemerintah.

Kinerja dalam argumentasi Colin Talbot dalam The Oxford Handbook of Public Management (2005: 500) menyebutkan terdapat dua fokus utama dalam kinerja yaitu apa yang disebut sebagai "outcome based governance" or outcome based budgeting" dan juga "what works"agenda. Kinerja dengan demikian bukan saja dilihat sebagai perbandingan input dan output atau efisiensi saja tetapi yang lebih penting adalah pada outcomes atau hasil yang telah dicapai. Selain itu kinerja juga harus mampu melihat pada apa yang menjadi agenda kerja organisasi untuk menghasilkan suatu pencapaian. Misalnya untuk meningkatkan derajat kesehatan masyarakat Banyumas Pemda Banyumas telah menyediakan anggaran untuk menampung masyarakat miskin yang belum masuk quota askeskin. Hal ini berkaitan dengan kebijakan serta implementasinya.

Persoalan kinerja bukanlah persoalan yang sederhana apalagi setiap kebijakan atau tindakan pemerintah akan menghasilkan banyak efek (multiplier effect). Maka akan banyak efek atau dampak yang harus diperhitungkan dalam mengevaluasi kinerja pemerintah daerah. Dalam kasus urusan kesehatan, kinerja pemerintah daerah Kabupaten Banyumas harus dilihat pada pencapaian derajat kesehatan masyarakat Banyumas, terutama pada warga miskin. Namun demikian dalam penelitian ini membatasi fokus kajian pada pencapaian keikutsertaan warga miskin dalam program Jaminan kesehatan dan berbagai persoalan yang ada di dalamnya. Hal ini penting karena adanya program Jaminan kesehatan untuk warga miskin (Jamkesmas) sebenarnya sangat membantu pemerintah daerah dalam meningkatkan derajad kesehatan masyarakat miskin. Karena program ini didanai oleh pusat (APBN) dan daerah hanya menyiapkan daftar kuota masyarakat miskin yang berhak mendapatkan pelayanan askeskin. 
Kinerja Program Kesehatan dalam Menjangkau Masyarakat Miskin: Studi Tentang Kapasitas Manajemen dalam Program Jaminan Kesehatan Masyarakat (JAMKESMAS) untuk Keluarga Miskin di Kabupaten Banyumas (Denok Kurniasih)

Dalam pelaksanaan program Jamkesmas ini, pemerintah pusat melalui APBN mendukung pembiayaan khususnya untuk operasional pelayanan kesehatan dengan sasaran sebanyak 76,4 juta jiwa. Namun di lapangan masih banyak ditemukan masyarakat miskin yang belum mendapatkan kesempatan. Oleh karena itu pemerintah daerah berkewajiban untuk dapat menyediakan kekurangan anggaran termasuk dukungan kebutuhan obat dan bahan habis pakai dan kebutuhan logistic lainnya. Karena dana Jamkesmas lebih banyak digunakan pada bantuan biaya pelayanan kesehatan dan operasional pelayanan secara terbatas.

Dengan adanya kewajiban tersebut, pemerintah daerah diharapkan mampu menutupi kekurangan dalam program Jamkesmas. Persoalan yang kemudian terjadi adalah pemerintah daerah belum memiliki kemampuan yang memadai untuk ikut serta memberikan Jamkesmas atau dalam istilah lain Jamkesda bagi masyarakat. Seperti yang terjadi di Kabupaten Banyumas, masih banyak masyarakat miskin yang belum tertampung dalam program Jaminan kesehatan untuk masyarakat miskin (Jamkesmas). Daerah tidak memiliki ukuran yang jelas berkaitan dengan ukuran warga miskin sesuai dengan karakteristik daerah. Yang digunakan adalah ukuran Badan Pusat Statistik (BPS) seperti kondisi rumah, kepemilikan kendaraan, anggota keluarga, pendapatan minimal dan sebagainya. Sehingga hal ini dimanfaatkan oleh banyak pihak untuk merekayasa atau menyalahgunakan kewenangan untuk menentukan sasaran. Termasuk juga didalamnya persoalan politik karena menyangkut janji-janji wakil rakyat pada saat kampanye dan persoalan kemampuan anggaran daerah juga. Dengan demikian dapat disimpulkan bahwa kegagalan pemerintah daerah dalam pendataan masyarakat miskin sangat berkaitan dengan kapasitas manajemen pemerintah daerah dan juga aspek politik yang ada di daerah. Kapasitas manajemen berkaitan dengan kemampuan sumberdaya manusia, kapasitas informasi terkait dengan sistem informasi dan juga kapasitas anggaran daerah.

Penelitian tentang kinerja yang menghubungkannya dengan kapasitas manajemen dikemukakan oleh Moynihan dan Ingraham (2001). Hasil penelitian mereka menghasilkan kesimpulan bahwa pemerintahan dengan kapasitas manajemen yang tinggi akan menghasilkan kinerja yang lebih baik. Kapasitas manajemen merupakan pra kondisi bagi kinerja, sehingga di dalamnya juga mengaitkan aspekaspek organisasi, seperti sumberdaya aparatur, keuangan, struktur dan kepemimpinan.

Dalam konteks pelayanan publik Boyne (2003) menyatakan bahwa hanya manajemen dan sumberdaya yang memperlihatkan hubungan signifikan dengan peningkatan pelayanan publik. Reiney (1999) dalam sebuah riset kualitatif juga menyebutkan bahwa manajemen diterima sebagai nilai penting dalam pencapaian organisasi pelayanan publik yang efektif (Rainey dalam Rainey and Steinbaver, 1999). Oleh sebab itu tulisan ini dilandasi oleh pemikiran terdahulu bahwa kinerja pelayanan publik sangat ditentukan oleh kapasitas manajemen dan juga aspek politik. 


\section{PERMASALAHAN}

Dampak dari adanya program Jamkesmas menyebabkan pemerintah daerah berkewajiban menyiapkan data yang akurat menyangkut masyarakat miskin sebagai penerima Jamkesmas. Namun demikian persoalan selalu terjadi manakala daerah menentukan mana masyarakat miskin yang memang berhak mendapatkan Jamkesmas dan mana yang tidak. Hal inilah yang menjadi sorotan banyak kalangan menyangkut aspek transparansi dan keadilan dalam menentukan sasaran program. Oleh karena itu dalam tulisan ini membatasi pada perumusan masalah : Mengapa kinerja pengelolaan Jamkesmas di Kabupaten Banyumas belum mampu menjangkau masyarakat miskin secara adil dan transparan?.

\section{METODE PENELITIAN}

Metode penelitian yang digunakan dalam penelitian ini menggunakan penelitian kualitatif dengan pendekatan interpretatif. Dalam hal ini Creswell (2009: 1) menyatakan bahwa penelitian kualitatif merupakan proses penyelidikan untuk memahami masalah sosial atau masalah manusia berdasarkan pada penciptaan gambaran holistik lengkap yang dibentuk dengan kata-kata, melaporkan pandangan informan secara terperinci dan disusun dalam sebuah latar alamiah.

Pengumpulan data dilakukan dengan wawancara mendalam terhadap informan yang terkait secara langsung dengan program Jamkesmas. Informan dalam penelitian ini terdiri dari Bagian Kesejahteraan Rakyat (Kesra) Setda, Kepala Dinas dan pegawai Dinas Kesehatan yang menangani program Jamkesmas serta masyarakat yang menerima dan tidak menerima program. Penelitian ini juga melakukan studi literatur dan studi dokumentasi untuk mengkaji berbagai bahan referensi seperti buku dan jurnal ilmiah serta dokumen yang ada dilapangan.

Tahapan analisis dilakukan melalui langkah-langkah sebagai berikut: (1) pengelompokkan data, (2) penguraian data berdasarkan kerangka teori, (3) pemaknaan data berdasarkan pendekatan interpretative social sciences. Teknik triangulasi juga dilakukan untuk melakukan cross check agar hasil analisis lebih obyektif.

\section{PEMBAHASAN \\ Kinerja Program Kesehatan bagi Masyarakat Miskin}

Pengukuran kinerja merupakan alat untuk menilai kesuksesan organisasi. Dalam konteks organisasi sektor publik, kesuksesan organisasi itu akan digunakan untuk mendapatkan legitimasi dan dukungan publik (Morphet, 2008: 58). Legitimasi dan dukungan publik dengan demikian dapat diperoleh manakala pemerintah mampu memberikan tuntutan akuntabilitas publik yaitu pertanggungjawaban pemerintah terhadap masyarakat yang seharusnya dilayani. Perwujudan dan komitmen yang nyata 
Kinerja Program Kesehatan dalam Menjangkau Masyarakat Miskin: Studi Tentang Kapasitas Manajemen dalam Program Jaminan Kesehatan Masyarakat (JAMKESMAS)

untuk Keluarga Miskin di Kabupaten Banyumas (Denok Kurniasih)

dari akuntabilitas publik tersebut hanya dapat ditunjukan dalam bentuk kinerja organisasi (Keban, 2005: 189).

Pembangunan dalam bidang kesehatan sesuai dengan Undang - Undang kesehatan Republik Indonesia Nomor 23 Tahun 1992 tentang pembangunan kesehatan, diarahkan untuk meningkatkan sumber daya manusia dan lingkungan yang saling mendukung dengan pendekatan paradigma sehat yang memberikan prioritas pada upaya peningkatan kesehatan, pencegahan, penyembuhan, dan rehabilitasi sampai usia lanjut. Selain itu juga untuk meningkatkan dan memelihara mutu lembaga serta pelayanan kesehatan melalui pemberdayaan sumber daya manusia serta berkelanjutan, dan sarana prasarana dalam bidang medis, termasuk ketersediaan obat yang bisa dijangkau oleh masyarakat.

Program kesehatan harus mampu menjangkau semua lapisan masyarakat. Artinya pengukuran kinerja program harus dilihat pada jumlah peningkatan cakupan layanan bagi masyarakat miskin. Semakin besar cakupannya maka semakin baik kinerjanya. Di Kabupaten Banyumas cakupan pelayanan kesehatan untuk orang miskin justru belum 100 persen namun baru mencapai 47,79 persen. Hal ini salah satunya disebabkan karena masih banyaknya warga miskin yang belum tertampung dalam program Jamkesmas. Keseluruhan kuota yang tersedia dalam Jamkesmas berjumlah 658.942 jiwa. Belum ditambah jumlah bayi lahir tahun 2009 yang dapat langsung cetak kartu jika salah satu orang tua bayi terdaftar sebagai peserta Jamkesmas, dengan syarat yang telah ditentukan. Sementara itu data dari BPS menyebutkan jumlah penduduk miskin di Banyumas mencapai 150.647 Rumah Tangga Miskin (RTM). Jika diasumsikan satu keluarga terdiri dari 4 jiwa maka terdapat 602.588 jiwa yang berhak mendapatkan Kartu Jamkesmas. sehingga terdapat sisa kuota sejumlah 56.357. Dengan melihat data tersebut, seharusnya seluruh masyarakat miskin dapat tertampung dalam program Jamkesmas.

Namun hasil penelitian menunjukan bahwa masih terdapat masyarakat miskin yang belum mendapatkan layanan Jamkesmas. Salah satu indikator kinerja program pelayanan kesehatan menunjukan bahwa cakupan pelayanan kesehatan rujukan pasien miskin hanya menunjukan angka 47 persen. Berdasarkan hasil wawancara dengan informan pasien miskin menjawab bahwa rumah sakit seringkali menolak pasien miskin yang belum memiliki kartu Jamkesmas sedangkan pengurusan administratif Jamkesmas lama dan berbelit-belit (hasil wawancara tanggal 16 Oktober 2009).

Rendahnya cakupan pelayanan kesehatan bagi masyarakat miskin menunjukan bahwa pemerintah Kabupaten Banyumas belum memberikan pelayanan yang adil dan merata. Padahal Gaster (1996) menyatakan bahwa pelayanan publik harus mampu mewujudkan tujuan masyarakat, menyeimbangkan kebutuhan dan keinginanan kelompok-kelompok yang berbeda dalam suatu masyarakat. Hal tersebut disebabkan karena pemerintah bertanggungjawab terhadap anggaran publik dan tidak hanya 
bertujuan memenuhi kebutuhan individu tetapi juga meningkatkan kualitas hidup keseluruhan masyarakat secara merata. Disinilah nilai penting pelayanan publik bagi kesejahteraan masyarakat.

\section{Kapasitas Manajemen dan Kinerja Program Kesehatan}

Menempatkan manajemen dalam upaya-upaya reformasi administrasi merupakan salah satu cara yang tepat untuk memperbaiki kualitas pelayanan. Aparatur pemerintah memiliki tugas menyediakan pelayanan, menegakkan hukum dan peraturan serta memecahkan masalah-masalah publik. Semua aktivitas ini membutuhkan adanya kapasitas manajemen. Seberapa baik kinerja pemerintah secara fundamental tergantung dari kapasitas manajemen yang dimiliki. Lynn, dkk (2003: 15) dalam reduce-form model, menyatakan bahwa kinerja pemerintah merupakan fungsi dari kapasitas manajemen dan serangkaian hambatan dan peluang dari lingkungan.

Carut marutnya persoalan Jamkesmas non quota ini pada akhirnya membawa konsekuensi pada kegagalan pelaksanaan pembangunan. Defisit anggaran yang terjadi di Kabupaten Banyumas merupakan gambaran akan buruknya perencanaan yang dilakukan oleh pemerintah daerah. Termasuk juga persoalan terhambatnya pelaksanaan program-program yang tadinya sudah masuk dalam Rencana Kerja Pembangunan Daerah. Misalnya saja rencana pembangunan infrastruktur pedesaan tidak berhasil terealisasi pada tahun anggaran 2009/2010.

Demikian juga dengan kemampuan Pemerintah Kabupaten Banyumas dalam mengelola informasi terkait dengan berapa jumlah masyarakat miskin. Selama ini Pemerintah Kabupaten Banyumas terus saja menerima data tambahan terkait dengan masyarakat miskin. Sebenarnya berapa kepastian jumlah penduduk miskin yang ada di Banyumas belum dimiliki oleh pemerintah daerah. Oleh karena itu kuota yang diterima dari pusat tidak sesuai dengan kenyataan yang ada. Pemerintah daerah sendiri hanya menggunakan pedoman pengukuran orang miskin berdasarkan indikator dari Badan Pusat Statistik.

Persoalan tersebut sangat berhubungan dengan kapasitas pemerintah daerah dalam hal pengelolaan berbagai sumber daya. Termasuk di dalamnya informasi menyangkut masyarakat miskin yang akurat. Konsep "kapasitas" menurut Ingraham (2005: 392) merupakan suatu platform for performance atau merupakan suatu prakondisi bagi performance. Kapasitas manajemen atau management capacity didefinisikan oleh Selden dan Sowa (2004) sebagai " The degree to which the necessary systems and process are in place to maintain an organization". Dalam kaitannya dengan pemerintah, kapasitas manajemen didefinisikan sebagai kemampuan yang melekat pada pemerintah untuk mengorganisasikan, mengembangkan, mengarahkan dan mengendalikan sumberdaya manusia, sumberdaya fisik dan capital formation untuk mendukung keleluasaan arah kebijakan (Ingraham dan Donahue, 2000: 294). Dalam pengertian yang lebih sederhana kapasitas manajemen akan 
Kinerja Program Kesehatan dalam Menjangkau Masyarakat Miskin: Studi Tentang Kapasitas Manajemen dalam Program Jaminan Kesehatan Masyarakat (JAMKESMAS) untuk Keluarga Miskin di Kabupaten Banyumas (Denok Kurniasih)

mengarahkan pemerintah pada kemampuan untuk mengelola berbagai sumberdaya untuk mendukung kinerja pemerintah. Oleh karena itu kapasitas manajemen seperti yang digambarkan sebagai sesuatu yang berada dalam kotak hitam merupakan faktor penentu kinerja (Ingraham, and Donahue, 2000).

\section{Kapasitas Anggaran dalam Program Jamkesmas}

Sebenarnya untuk mengatasi kurangnya anggaran Jamkesmas yang disediakan pemerintah pusat, Pemerintah Kabupaten Banyumas telah membuat kebijakan untuk menanggung beban anggaran kesehatan masyarakat miskin melalui dana bantuan sosial untuk pembiayaan pelayanan kesehatan bagi masyarakat miskin. Hal ini diperjelas dalam Peraturan Bupati Banyumas No 30 Tahun 2008. Namun demikian pemberian bantuan kesehatan bagi masyarakat miskin yang disebut juga jamkesmas non quota ini juga mengalami kendala dan pada akhirnya program ini dihentikan pada tahun 2009. Penyebabnya adalah:

1. Anggaran Pemerintah Kabupaten Banyumas telah defisit Rp 1,3 Milyar (hanya dengan Rumah Sakit Margono) data per Mei 2009

2. Masyarakat yang menggunakan Surat Keterangan Tidak Mampu (SKTM) tidak terkontrol

3. Kenaikan tarif di Rumah Sakit rujukan

Kondisi ini kemudian menyebabkan beban anggaran daerah semakin besar sehingga mengganggu program-program pembangunan yang lain. Total dana APBD dan perubahan yang sudah digelontorkan untuk jamkesmas non kuota ini adalah sebesar Rp. 3.100.000.000,00. Oleh karena itu Pemda Banyumas berupaya untuk mengusulkan kembali kuota Jamkesmas kepada pemerintah pusat. Jumlah terakhir data yang diterima bagian kesejahteraan rakyat sekretariat daerah Kabupaten Banyumas menyebutkan bahwa sejumlah kurang lebih 9.500 kartu sudah diusulkan kepada menteri kesehatan supaya kartu tersebut dapat dicetak dan digunakan bagi yang berhak. Namun sampai sekarang belum terealisasi.

Kinerja pelayanan kesehatan untuk masyarakat miskin jelas-jelas belum berdampak nyata. Hal ini terjadi karena cakupan layanan pendataan Jamkesmas belum maksimal. Sehingga masih banyak masyarakat miskin yang belum mendapatkan pelayanan kesehatan dengan baik. Dilihat dari fenomena yang terjadi hal ini berkaitan dengan kapasitas manajemen anggaran pemerintah daerah. Selain itu persoalan tambahan anggaran untuk menalangi jamkesmas non kuota ini pada akhirnya menyebabkan banyaknya program-program yang sudah direncanakan menjadi gagal dilaksanakan. Karena APBD menaggung biaya bagi Jamkesmas non quota. Padahal menurut perhitungan quota dari pusat masih bisa memenuhi keseluruhan masyarakat miskin yang ada di Banyumas. Hamun quota tersebut justru digunakan oleh pihakpihak tertentu untuk menampung masyarakat yang seharusnya tidak menerima. 
Pelaksanaan penganggaran merupakan fungsi yang sangat pelik bagi administrasi publik modern. Terdapat dua dimensi penting dalam penganggaran yaitu hubungan antara pemerintah lokal dengan negara (the state) dan hubungan antara pemerintah lokal dengan masyarakat (the citizen) (Morphet, 2008: 94). Kedua dimensi ini harus dijalankan secara berimbang. Dalam arti bahwa penganggaran harus akuntabel kepada pemerintah pusat sebagai pemberi kewenangan dan juga masyarakat sebagai pemberi mandat anggaran.

Salah satu aspek penting dalam penganggaran adalah aspek politik. Hal ini seringkali sulit dibuktikan namun sangat terlihat nyata peranannya. Penyelenggaraan kegiatan pemerintahan tidak akan terlepas dari persetujuan DPRD. Oleh karena itu berapa dan bagaimana rincian anggaran yang diperlukan untuk melakukan semua kegiatan pemerintahan daerah merupakan hasil kesepakatan antara eksekutif dan legislatif. Di sinilah sering terjadi tawar-menawar anggaran, terutama pada penentuan prioritas yang sesuai dengan kebutuhan dan potensi daerah. "Lobi politik" akan sangat terlihat dalam tahapan ini.

\section{Kapasitas Informasi dalam Program Jamkesmas}

Salah satu upaya untuk meningkatkan kualitas pelayanan publik adalah melibatkan masyarakat sebagai sumber informasi. Selama ini pemerintah terlalu percaya diri dengan produk yang mereka hasilkan. Penelusuran terhadap kepuasan pelanggan merupakan bagian dari pengumpulan informasi yang penting bagi organisasi. Dalam pelayanan publik hal yang jarang dilakukan adalah membuat standar pelayanan minimal (SPM). Hal ini penting dilakukan agar harapan konsumen dan provider dapat dipertemukan. Pelayanan publik oleh karena itu perlu untuk melibatkan masyarakat dalam membuat standar kualitas.

Doherty dan Horne (2002) menjelaskan bahwa anggota organisasi publik harus aktif terlibat dalam penilaian kualitas dari pekerjaan yang dilakukan organisasi. ketika inisiatif untuk memperbaiki kualitas gagal, ini bisa jadi karena warga masyarakat tidak merefleksikan nilai yang berkembang di masyarakat yang dapat menimbulkan budaya organisasi. dengan demikian kapasitas informasi sangat penting bagi perbaikan kualitas pelayanan publik.

Di tengah perkembangan era globalisasi saat ini, kebutuhan akan informasi semakin urgen. Konsep "knowing organization" menjadi penting untuk diadopsi. Karena knowing organization memberi kesiapan pada organisasi untuk menjaga keberlangsungan pertumbuhan dalam lingkungan yang dinamis. Dengan memahami lingkungan sekitar maka organisasi akan dapat menyesuaikan diri lebih awal. Pada intinya knowing organization merupakan manajemen dari proses-proses informasi yang bermanfaat bagi sensemaking, knowledge creating and decision making ( Wei Choo, 2001).

Dalam konteks pelayanan publik keterbukaan terhadap konsumen merupakan bagian dari upaya mendapatkan informasi. Oleh karena itu mekanisme voice dalam 
Kinerja Program Kesehatan dalam Menjangkau Masyarakat Miskin: Studi Tentang Kapasitas Manajemen dalam Program Jaminan Kesehatan Masyarakat (JAMKESMAS) untuk Keluarga Miskin di Kabupaten Banyumas (Denok Kurniasih)

pelayanan publik perlu untuk dikuatkan. Kritik masyarakat akan membantu pemerintah dalam peningkatan kualitas pelayanan. Dengan mengetahui keluhan masyarakat maka pemerintah akan mengetahui harapan masyarakat. Proses ini akan memunculkan standar pelayanan minimal yang sebenarnya dibutuhkan masyarakat.

Terkait dengan akurasi data peserta askeskin, maka pemerintah daerah harus senantiasa melakukan upaya validasi disetiap tingkatan termasuk oleh kepala desa. Hal inilah yang sedang direncanakan oleh Pemda Banyumas agar data yang diperoleh dapat lebih valid. Upaya tersebut meliputi.

1. Validasi data Askeskin yang sudah ada, apakah sudah tepat sasaran atau belum

2. Menempelkan daftar penerima kartu dibalai desa agar masyarakat dapat ikut memvalidasi data (kontrol moral)

3. Mendata kembali jika terdapat masyarakat yang berhak mendapatkan tetapi belum mendapat kartu Askeskin (sesuai kemiskinan BPS)

4. Melakukan sosialisasi kepada warga masyarakat

5. Membuat surat keputusan bersama BPD dan atau LKMD tentang masyarakat miskin di wilayah masing-masing

6. Menyetorkan data tersebut ke bagian kesra dalam bentuk softcopy dan copy surat keputusan yang dimaksud.

Pengelolaan informasi yang akurat tentunya membutuhkan kualitas sumberdaya manusia serta teknologi yang berkualitas. Oleh karena itu dukungan terhadap program pendataan masyarakat miskin ini juga perlu mendapatkan dukungan anggaran dari APBD. Dengan demikian dapat disimpulkan bahwa kinerja pemerintah tidak akan terlepas dari fungsi kejelasan tujuan, kapasitas manajemen dalam hal ini sumberdaya manusia, anggaran dan informasi serta development culture (Pandey, Coursey dan Moynihan (2004).

\section{Kapasitas Sumberdaya Manusia dalam Program Jamkesmas}

Masalah pelayanan publik memang akan sangat luas sekali. Banyak perspektif yang bisa digunakan untuk mengkaji pelayanan publik. Berdasarkan sistematika dan prosedur pelayanan kita dapat melihatnya melalui kajian kelembagaan. Dari sisi pelaksanaannya kita bisa lihat dari perspektif manajemen sumberdaya manusia. Dari besarnya kewenangan kita bisa melihat dari sisi desain kebijakannya. Oleh karena itu apabila kita ingin melakukan reformasi pelayanan publik, maka tinjauannya bisa dari berbagai aspek kajian.

Pengelolaan aparatur pemerintah dengan organisasi privat memiliki perbedaan. Aparatur pemerintah yang dalam istilah asing disebut civil servant menghasilkan produk yang berbeda dengan privat servant. Aparatur pemerintah menghasilkan pelayanan publik. Pelayanan publik tidak seperti industry manufaktur barang, pelayanan publik adalah sesuatu yang bersifat intangiable dan konsumen secara 'intim' terlibat dalam service delivery (Doherty and Horne, 2002). Kenyataan inilah yang 
menyebabkan sulitnya melakukan penilaian dan spesifikasi terhadap kualitas pelayanan publik.

Farnham and Horton (Doherty and Horne, 2002) menjelaskan bahwa diperkenalkannya new managerialism yang seringkali disebut sebagai NPM, akan dapat menjadi jalan untuk meningkatkan kekuatan professionalisme dalam pelayanan publik. Di United Kingdom telah lama mengubah wacana professional menjadi publik manajer. Manajer lebih entrepreneurial dan bekerja berdasarkan apa yang dibutuhkan oleh market. Demikian pula di Amerika Serikat pada saat Clinton memperkenalkan Reinventing Government.

Dalam organisasi publik pegawai merupakan aset organisasi yang sangat berharga. Tugas negara adalah menyelenggarakan urusan publik, oleh karena itu negara membutuhkan pegawai yang dapat menyelenggarakan urusan publik dengan baik. Hal ini menuntut adanya sistem rekruitmen yang sesuai dengan kebutuhan. Rekruitmen ini menjadi wacana penting dalam personel manajemen karena selama ini organisasi publik tidak pernah memiliki standar rekruitmen yang menganut prinsip merit system. Merit system merupakan prinsip dimana seseorang diterima bekerja atas dasar kemampuan yang dimiliki dimana kemampuan tersebut sesuai dengan tugas dan pekerjaan yang ada dalam organisasi (Dresang, 2002:17).

Sesuai prinsip merit system, organisasi publik membutuhkan pegawai yang sesuai dengan karakteristik pekerjaan di sektor pulik. Di AS public personnel management telah bergerak dari yang tadinya hanya mengurus tugas-tugas tata usaha menjadi multifacet dari responsibilitas yang harus dikembangkan. Proses seleksi yang tadinya informal berubah menjadi melalui tahapan-tahapan yang secara ideal meliputi analisis posisi, rekruitmen yang didesain untuk menampilkan kandidat yang kualified dengan tidak membedakan kelompok minoritas, melakukan tes yang valid dan seleksi interview.

Proses rekruitmen yang benar akan menghasilkan pegawai yang sesuai kebutuhan. Sebenarnya sebelum melakukan rekruitmen pegawai, organisasi sudah harus melakukan analisis jabatan (job analysis). Landasan yang paling mendasar dari manajemen sumber daya manusia adalah analisis pekerjaan (job analysis). Analisis jabatan menurut Groover (2007: 721) adalah suatu proses untuk mendapatkan dan mendokumentasikan semua informasi tentang jabatan yang spesifik, kinerja, tanggung jawab, keterampilan dan pengetahuan yang dibutuhkan. Menurutnya proses dalam analisis pekerjaan akan menghasilkan deskripsi pekerjaan (job description). Di dalam deskripsi pekerjaan mencangkup job title (jabatan), tugas dan tanggungjawab, kualifikasi yang dibutuhkan dan kondisi kerja.

Dengan melakukan proses-proses dalam manajemen personal maka diharapkan tidak ada lagi pegawai yang salah posisi atau tidak memahami pekerjaannya. Misalnya di Kabupaten Banyumas, pegawai pada Kantor Perpustakaan Daerah tidak ada yang murni seorang pustakawan. Justru Kantor Perpustakaan Daerah identik dengan kantor 
Kinerja Program Kesehatan dalam Menjangkau Masyarakat Miskin: Studi Tentang Kapasitas Manajemen dalam Program Jaminan Kesehatan Masyarakat (JAMKESMAS)

untuk Keluarga Miskin di Kabupaten Banyumas (Denok Kurniasih)

buangan. Pegawai-pegawai yang tersingkir baik secara politis maupun professional biasanya ditempatkan di unit-unit yang dianggap tidak strategis.

Seharusnya birokrasi pelayanan bersifat netral. Apabila mengacu pada prinsip merit system, maka pegawai di sektor publik haruslah secara politik netral. Alasannya sangat sederhana, kalau mereka tidak netral maka birokrasi tidak akan pernah menjadi organisasi yang mapan. Birokrasi akan terus mengikuti arah pergerakan regim (Dressang, 2002: 40). Di Inggris prinsip ini telah menjadi tradisi yang terus dijalankan. Birokrasi concern pada pelayanan publik. Hal inilah yang belum terjadi di Indonesia.

Birokrasi harus netral karena mereka seharusnya hanya berhadapan dengan masyarakat. Khususnya pada unit organisasi yang langsung melayani masyarakat, pegawai pemerintah harus senantiasa responsif serta mampu menyelesaikan masalah dengan cepat. Oleh sebab itu posisi front-line officer sebenarnya justru sangat penting. Seperti juga yang dilakukan di AS, front-line memiliki kewenangan yang besar dalam menentukan setiap tindakan. Sehingga hierarkhi yang panjang tidak berlaku disana.

Berbeda dengan di Indonesia birokrasi weber justru menyebabkan rantai komando yang panjang. Sehingga responsivitas sulit didapat karena panjangnya jalur yang harus dilalui untuk menyelesaikan masalah. Yang terjadi setelahnya justru kebocoran dalam kewenangan (linkage of authority) dimana kebijakan pimpinan ditafsirkan salah (Sinambela, 2006:35). Oleh karena itu birokrasi pelayanan perlu diarahkan menjadi organisasi yang pembelajar (learning organization). Peter Senge memperkenalkan learning organization sebagai organisasi yang selalu adaptif terhadap perubahan dan menjadi pelopor bagi perubahan (Senge, 1996).

\section{Aspek Politik dalam Kinerja Program Jamkesmas}

Persoalan warga miskin seringkali dikaitkan dengan aspek politik. Warga miskin merupakan komoditas politik yang hanya dimanfaatkan pada saat kampanye para wakil rakyat. Artinya hubungan antara warga miskin dengan wakil rakyat merupakan hubungan sesaat yang dipenuhi dengan kepentingan-kepentingan sesaat pula. Akibatnya pemerintahan berjalan tanpa keberlanjutan hubungan yang jelas. Dan hal ini menyebabkan rendahnya akuntabilitas kinerja pemerintahan terhadap masyarakat. Di banyak negara modern demokratik, kinerja dibangun dalam lingkungan politik dimana mereka akan berkompetisi memberikan janji "the good life". Sehingga kinerja pemerintah tidak akan bisa dilepaskan dari politik. Karena masyarakat pemilih akan terus berjuang dalam menagih janji dan menilai kinerja masa lalu. (Talbot, 2005:491).

Oleh karena itu wajar jika rakyat kemudian berupaya menuntut janji-janji yang telah disampaikan pada saat kampanye. Di Kabupaten Banyumas masyarakat terus saja menagih janji pemerintah. Dalam harian Kompas diberitakan : 
Puluhan orang berunjuk rasa di Kantor Bupati Banyumas, mereka kecewa karena pemerintah kabupaten Banyumas belum juga meningkatkan dan mewujudkan layanan kesehatan gratis, pendidikan gratis, dan pengurangan kemiskinan. Akan tetapi, pemerintah kabupaten Banyumas justru sibuk menganggarkan dana untuk pembangunan fisik. (Kompas, Edisi Rabu 29 Juli 2009).

Kekecewaan masyarakat tersebut seolah ingin membenarkan pendapat Svensson (2008) bahwa persoalan utama dalam birokrasi adalah responsivitas. "Lack of Responsiveness has been one of the major criticism of bureaucratic agencies". (Svensson, 2008). Lebih lanjut Svensson juga menjelaskan bahwa sistem birokrasi tidak diciptakan sensitive dan responsif terhadap kondisi dan situasi yang non standar. Misalnya saja pada saat kuota Jamkesmas dari pemerintah pusat tidak mencukupi kebutuhan daerah, maka daerah tidak memiliki kemampuan untuk mengatasi masalah tersebut. Yang ada justru tarik ulur kepentingan pejabat yang mengorbankan kepentingan masyarakat.

Unjuk rasa tersebut merupakan gambaran ketidakpuasan masyarakat terhadap kinerja pemerintah daerah dalam memberikan pelayanan publik. Masyarakat kemudian menggunakan segala cara untuk mendapatkan pelayanan yang telah dijanjikan. Termasuk dengan memanfaatkan posisi anggota DPRD untuk mendapatkan akses pelayanan kesehatan. Dalam kasus kuota Jamkesmas dari hasil wawancara ternyata terdapat sekelompok masyarakat yang memang menggunakan cara-cara demikian untuk dapat masuk dalam kuota jamkesmas. Hal ini tentu saja menyebabkan ketidaksinkronan antara data yang diperoleh dari eksekutif dengan data tambahan dari cara yang demikian. Akibatnya terjadi tumpang tindih data dan kriteria warga miskin tidak terpenuhi. Masyarakat yang seharusnya masuk kuota justru tidak bisa masuk kuota karena sudah diisi oleh warga yang lain.

Masalah tersebut memberikan gambaran bahwa organisasi publik memang bekerja dalam sebuah lingkungan yang unik, yaitu lingkungan politik (Rosyadi, 2010:67). Menurut Vigoda (2000), lingkungan politik organisasi publik dapat menghambat fleksibilitas dan kapabilitas professional pelayanan public dalam menanggapi tuntutan publik. Hal ini disebabkan oleh motif-motif sesaat yang ditunjukan oleh para pejabat public yang dipilih pada saat pemilihan. Dalam kasus pendataan Askeskin, aspek politik mengakibatkan kegagalan pemerintah dalam mengagendakan pelayanan kesehatan yang menjangkau masyarakat miskin. Karena tidak semua warga miskin mendapatkan Askeskin dan justru terdapat masyarakat yang tidak berhak dapat masuk dalam kuota Askeskin.

Pelayanan publik sangat berhubungan dengan politik (Hilton Dawson dalam Doherty and Horne, 2002: 12). Politik dapat membantu merubah kultur dalam pelayanan publik. Dari yang tadinya berorientasi pelanggan menjadi lebih berorientasi pada warga negara atau justru sebaliknya. Contohnya terjadi di Kabupaten Banyumas. Ketika menentukan siapa yang berhak masuk dalam kuota Jamkesmas menjadi ajang 
Kinerja Program Kesehatan dalam Menjangkau Masyarakat Miskin: Studi Tentang Kapasitas Manajemen dalam Program Jaminan Kesehatan Masyarakat (JAMKESMAS)

untuk Keluarga Miskin di Kabupaten Banyumas (Denok Kurniasih)

kekuatan politik antara eksekutif dan legislatif. Perubahan budaya yang lebih berorientasi pada masyarakat tidak dapat terwujud manakala para politicians tidak mendorong terjadinya hal tersebut.

Sulitnya mewujudkan kualitas pelayanan publik memang disebabkan karena adanya ketimpangan yang terjadi dalam penyelenggaraan pelayanan publik. Dalam beberapa kasus, pemerintah daerah cenderung lebih mementingkan kepentingan sekelompok elit yang ada. Pandangan politicians dengan birokrasi berbeda bahkan timpang. Anne (dalam Doherty and Horne, 2002) menyebutkan ada beberapa ketimpangan yang seringkali menghambat kinerja pelayanan publik:

a. Gaps between expectations and service

b. Gaps between specifications and service

c. Gaps between management expectations and what front-line staff do

d. Gaps between politicians' views and the views of professionals in the service.

Kualitas pelayanan menjadi sulit terwujud dengan adanya ketimpangan tersebut, . Lebih lanjut Anne menyebutkan bahwa untuk mengatasi ketimpangan tersebut maka reformasi pelayanan publik perlu difokuskan pada membangun komunikasi, spesifikasi pelayanan, delivery, manusia dan sistem pelayanan (Doherty and Horne, 2002:156).

Persoalan pendataan kuota Askeskin memang sangat berkaitan dengan kapasitas manajemen pemerintah daerah dan juga lingkungan politik yang mendukung. Peningkatan akurasi pendataan menjadi tanggungjawab aparat dan lingkungan politik harus bisa mendukung. Pemanfaatan teknologi informasi disinyalir dapat memberikan dukungan akurasi serta mengeliminasi lingkungan politik yang kurang baik. Penggunaan electronic government ini setidaknya akan mampu mengubah pola interaksi antara pemerintah dengan masyarakat (Holmes, 2001). Lingkungan politik yang kurang baik akan bisa lebih diatasi dengan pemanfaatan teknologi informasi yang akurat. Sehingga yang lebih dibutuhkan adalah kapabilitas pemerintah daerah. Dave Ulrich and Nom Smallwood, (2009: 14) menyatakan bahwa Capabilities represent what the organization is known for, what it is good doing, and how it pattern its activities to deliver value. Karena kembali pada pemahaman tentang kinerja pemerintah daerah yang tidak saja menciptakan efisiensi dan efektivitas tetapi yang terpenting adalah menciptakan nilai outcome yang benar-benar terjadi pada masyarakat miskin.

\section{KESIMPULAN}

Kinerja Pemerintah Daerah dalam program kesehatan masih rendah. Dalam kasus pengelolaan Jamkesmas di Kabupaten Banyumas, rendahnya kinerja program ditunjukan dengan cakupan pelayanan terhadap Jamkesmas yang masih rendah. Masyarakat miskin banyak yang belum memiliki Kartu Jamkesmas sebagai syarat 
mendapatkan pelayanan kesehatan yang tersedia. Hal tersebut disebabkan oleh rendahnya kapasitas manajemen dari pemerintah daerah dan juga aspek politik yang ada dalam lingkungan pemerintah Kabupaten Banyumas. Kapasitas manajemen menyangkut kelemahan sumberdaya manusia, kapasitas anggaran dan kapasitas informasi dan aspek politik menyangkut komitmen dari DPRD untuk mendukung peningkatan kinerja pelayanan. Penentuan kuota Jamkesmas yang tidak tepat sasaran, ketidakjelasan informasi terkait kriteria masyarakat miskin, kualitas pelayanan yang rendah dan kemampuan anggaran daerah serta tarik menarik kepentingan politik penguasa. Dan hal ini memberi efek pada kegagalan program pembangunan yang lain akibat terserapnya dana sektor publik untuk sektor bantuan kesehatan masyarakat miskin.

\section{SARAN}

Beberapa hal yang perlu dilakukan oleh Pemerintah Kabupaten Banyumas adalah:

1. Meningkatkan kapasitas manajemen melalui peningkatan kapabilitas sumberdaya manusia, komitmen anggaran dan juga pengelolaan informasi yang berkualitas.

2. Menyelenggarakan sistem pendataan berbasis teknologi informasi untuk meningkatkan akurasi dan kecepatan pendataan warga miskin.

3. Peningkatan koordinasi dan pengawasan antara pemerintah dan DPRD agar tidak terjadi saling tumpang tindih kewenangan melalui kegiatan monitoring.

\section{DAFTAR PUSTAKA}

Boyne. 2003. What is Public Service Improvement?, Public Administration Review 81 (2); 211.

Burhanudin, Mohamad. 2009. Bupati Banyuman Dinilai Ingkar Janji. http://regional.kompas.com/read/xml/2009/07/29/20335676/Bupati Banyumas Dinilai Ingkar Janji. Diakses tanggal 11 Agustus 2009.

Creswell, John.W. 2007. Research design, Qualitative \& Quantitative Approaches, Sage Publications, Inc.

Doherty, Horne. 2002. Managing Public Services-Implementing Changes, A Thoughtful Approach to The Practice of Management, Routhledge, London and New York.

Dressang. 2002. Public Personnel Management and Public Policy, Fourth Edition, Longman, New York.

Dwiyanto, Agus. 2006. Reformasi Birokrasi Publik, UGM Press, Yogyakarta. 
Kinerja Program Kesehatan dalam Menjangkau Masyarakat Miskin: Studi Tentang Kapasitas Manajemen dalam Program Jaminan Kesehatan Masyarakat (JAMKESMAS)

untuk Keluarga Miskin di Kabupaten Banyumas (Denok Kurniasih)

Groover, M.P. 2007, Work Systems and The Methods, Measurement and Management of Work, Pearson International Edition Australia PTY Limited, Australia.

Gaster, L. 1995. Managing Quality in Public Service, Oxford University Press.

Holmes, D. 2001. eGov: e-business Strategies for Government, London, Nicholas Brealy.

Ingraham, P.W. 2005. Performance: Promises to Keep and Miles to Go. Public Administration Review: jul/Aug 65, 4: 390.

Ingraham, P.W. and A.E. Donahue, 2000. Dissecting the Black Box Revisited: Characterizing Government Management Capacity, in C. Heinrich and Lynn (Eds) Governance and Performance: New Perspective. Washington D.C: Georgetown University.

Keban, Yeremias. 2004. Enam Dimensi Strategis Administrasi Publik, Konsep, Teori dan Isu, Yogyakarta: Gava Media.

Lynn, dkk. 2000. Studying Public Management: Challenges and Prospect, journal of Public Administration research and Theory, 10 (2).

Morphet, Janice. 2008. Modern Local Government, Sage Publications Ltd, London.

Pandey, Sanjay K, Coursey, Moynihan. 2004. Organization Culture, ed Tape and Performance. Departement of Public Policy and Administration, Rutgers University.

Poister. 2003. Measuring Performance in Public and Non profit organizations, San Fransisco: Jossey-Bass

Pollit, C, Bouckaert G. 1995. Quality Improvement in European Public Service, Concept, Cases and Community, Sage.

Pollit, C. 1987. Capturing Quality? The Quality Issues in British and American Health Policies, Journal of Public Policy vol 71, No 1 p.71-87.

Rainey H, Steinbaver. 1999. Galloping Elephans; Developing Elemen of a Theory of Effective Government Organization, Journal of Public Administration Research and Theory 9: 1-32. 
Rosyadi, Slamet. 2010. Paradigma Baru Manajemen Pembangunan, Gava Media, Yogyakarta.

Sinambela. 2006. Reformasi Pelayanan Publik, Teori, Kebijakan dan Implementasi, Bumi Aksara, Jakarta.

Selden, Sowa. 2004. Testing a Multi-dimensional Model of Organizational Performance: Prospects and Problems. Journal of Public Administration Research and Theory, vol 14 , No 3.

Sole, Fransisco. 2009. A Management Model and Factors Driving Performance in Public Organizations, Measuring Business Excellence, $Q$ Emerald Group Publishing Limited, ISSN 1368-3047. Vol 13 No 4, p.3-11,

Siddique. 2006. Public Management Reform in Malaysia, recent Initiatives and Experiences, International Journal of Public Sector Management, Vol 19 No 4 p. 339-358.

Svensson, Jorgen, dkk. 2008. Reemployment Services in The Netherlands: A Competitive Study of Bureaucratic, Market and Network Forms of Organization.

Senge, Peter M. 1996. The Fifth Dicipline, The Art and Practice of The Learning Organization. New York : Doubleday.

Talbot, Collin. 2005. Performance Management, Ewan Ferlie, Laurence Lynn and Christopher Pollit (Edited), The Oxford Handbook of Public Management, Oxford University Press, New York.

Tjiptono. 2008. Service Manajement, Mewujudkan Pelayanan Prima, Penerbit Andi, Yogyakarta.

Ulrich, Dave and Norm Smallwood. 2009. Organization is Not Structure But Capability, in Frances Hesselbein and Marshall Goldsmith, eds. The Organization of The Future: Visions, Strategies, and Insights on Managing in New Era, San fransisco, Jossey-Bass

Vigoda, Eran. 2000. Are You being served? The Responsiveness of Public Administration to Citizens Demans: An Empirical Examination in Israel. Public Administration Vol.78, No.1: 165-191. 
Kinerja Program Kesehatan dalam Menjangkau Masyarakat Miskin: Studi Tentang Kapasitas Manajemen dalam Program Jaminan Kesehatan Masyarakat (JAMKESMAS)

untuk Keluarga Miskin di Kabupaten Banyumas (Denok Kurniasih)

Wei, Choo. 2001. Knowing Organization as Learning Organization, Education and Training, 43, 4/5; ABI/INFORM Global, p. 197. 